Ilmu Pertanian (Agricultural Science)

Vol. 1 No.2 August, 2016 : 067-073

Available online at http://journal.ugm.ac.id/jip

DOI: doi.org/10.22146/ipas.10656

ILMU PERTANIAN

(AGRICULTURAL SCIENCE)

\title{
Performance of Village Unit Co-Operatives in Yogyakarta Special Region: A Data Envelopment Analysis Approach
}

\author{
Abi Pratiwa Siregar*, Jamhari, Lestari Rahayu Waluyati \\ Department of Agricultural Socio Economics, Faculty of Agriculture, Universitas Gadjah Mada \\ Jln. Flora no. 1, Bulaksumur, Sleman, Yogyakarta 5528, Indonesia \\ *Corresponding email: abipratiwa@gmail.com
}

Received: $21^{\text {st }}$ April 2016 ; Revised: $7^{\text {th }}$ June 2016 ; Accepted: $10^{\text {th }}$ August 2017

\begin{abstract}
This study assessed the performance of 32 village unit co-operatives (KUD) in Yogyakarta Special Region during 2011 to 2012. The efficiency level of the KUD were evaluated by employing the data envelopment analysis and multiple regression analysis using panel data to determine the factors affecting efficiency level. Efficiency analysis was decomposed into three dimensions to explore possible sources of inefficiency. According to Marwa and Aziakpono (2016), the first dimension was technical efficiency, which explored the overall effectiveness of transforming the productive inputs into desired outputs compared to the data-driven frontier of best practice. The second dimension was pure technical efficiency, which captured managerial efficiency in the intermediation process. The third dimension was scale efficiency, which explored whether KUD were operating in an optimal scale of operation or not. The results found that the average scores are $64 \%, 92 \%$, and $68 \%$ for technical, pure technical, and scale efficiency respectively in 2011, while in 2012 the average scores are $57 \%, 94 \%$, and $60 \%$ for technical, pure technical, and scale efficiency. Factors having significantly positive impact on several measures of efficiency are incentive and dummy variables (agriculture inputs and hand tractor). Accounts receivable only has positive relationship to pure technical efficiency. On the other hand, rice milling unit and electricity services have negative impact with several measures of efficiency.
\end{abstract}

Keywords: Data Envelopment Analysis, Determinant, Efficiency, Village Unit Co-Operatives, Yogyakarta Special Region

\section{INTRODUCTION}

KUD is a multi-business unit co-operatives where the members are residents of villages located in the same district (Hadisapoetro, 1975). At the beginning, there were three stages in terms of developing KUD, namely: 1) Ofisialisasi. The government had a dominant role, since the establishment until its development, 2) Deofisialisasi. The government gradually reduced its intervention, and 3) Otonomi. KUD is already independent and can make its own decision for its activities. In other word, KUD is no longer relying on government facilities (Djohan, 1997).

The magnitude of the government roles through regulation, assistance, and facilities had resulted in the rapid development of co-operatives. Nevertheless, the growing point is mainly on the quantity, it does not followed by the quality. When the government forced the co-operatives to be independent, through
Presidential Instruction No. 18/1998, there are many co-operatives that cannot continue its activity. This is due to the inability of KUD to run its activities without government intervention. In addition, the other factors that caused such failure are the lack of active members and the management (weak managerial capacity and abuse of authority). In 2015, Yogyakarta Special Region has 63 KUD which spread over its regency and municipality. Jamhari et al. (2015) states that out of 63, there are 7 inactive KUD.

Basically, although it was established from a group of people rather than a collection of capital, co-operative should work efficiently. According to Ariyaratne et al. (2000), efficient is a very important thing for any co-operative. The more efficient a cooperative, then the high cost service could be reduced to a certain point. Furthermore, the decrease in costs will generate a positive influence on the member purchasing power or ability to pay.

Altman (2015) mentioned that the efficiency is 
one of the reasons for farmers to join co-operatives. The existence of co-operatives as a party that market the product and provide input of production, is expected to encourage a decline in per unit costs borne by farmers. In addition, from the perspective of farmers, co-operatives are able to improve their negotiation power and reduce market risk (Huang et al., 2013). The background is that farmers no longer act individually, but have been flocking. Therefore, the efficiency of the co-operatives become crucial. If in carrying out its activities, the co-operative cannot operate efficiently, then the goals cannot be realized.

In addition to improving service to members, efficiency is also one of the important parameters for the competitiveness. In this globalization era, cooperatives must continuously maintain and improve its efficiency. The goal is to be able to operate, thrive, and compete with the other economic actors. Co-operatives that are not able to increase its efficiency will slowly eliminated (Sularso cit. Davis, 2010; Huang et al., 2013).

There are numerous studies on co-operatives efficiency, such as Ganesan, (2009), Huang et al. (2013), and Othman et al. (2014). Ganesan (2009) conducted a study on the efficiency of co-operative banks. Input variables are number of members, number of branches, number of employees, and the amount of borrowed funds. On the other hand, the output variables used as a benchmark are the amount of savings, total amount of investment, and progress. This study found that during 2002 to 2006, the average score of efficiency of 30 state co-operative banks (SCBs) is $74.5 \%$. Meanwhile, out of 20 district central co-operative banks (DCCBs), the average level of efficiency is $72.51 \%$.

Inputs used by Huang et al. (2013) are capital, amount of labour, and other expenses, while the output is total revenue. From this study, it is concluded that out of 896 farmer co-operatives in Zhejiang in 2009, the level of technical efficiency, pure technical efficiency and scale efficiency are $0.46,0.59$, and 0.78 . The majority of technical efficiency values ranging between 0.3 and 0.6 . Only three co-operatives that have value above 0.9 . In addition, 14 co-operatives have pure technical efficiency values below 0.2 , and 89 co-operatives have value above 0.9 . Overall, the scale efficiency score is above 0.7 .

Othman et al. (2014) studied the efficiency of cooperative groups. Number of members, assets, and equity are determined as input, while turnover and profits become the output. The results showed that out of the 56 co-operative group, only $19.6 \%$ achieve efficient $(100 \%$ or 1$)$. These results indicate that the co-operative groups operate below optimal scale.

Based on the explanations that have been described, this study aims to determine the efficiency level and determine the factors that affect the efficiency level of KUD in Yogyakarta Special Region.

\section{MATERIALS AND METHODS}

\section{Methodology}

Data used in this study are secondary data that are obtained from Central Bureau of Statistics (BPS), Department of Industry, Trade and Co-operatives (Disperindagkop), and Annual Members Meeting (RAT) report of KUD during 2011 until 2012. The data contain organizational structure of KUD, balance sheet and income statement, as well as other data related to the study.

KUD's efficiency level obtained through analysis using Data Envelopment Analysis (DEA). Duguleana and Constantin (2015) mentioned that DEA is a method used for measuring the relative efficiency of a certain number of producers called decision making units (DMUs), being a set of comparable units. Each DMU has inputs and outputs. The efficiency score of a DMU is a value between 0 and 1 ; the value 1 indicates a relatively efficient DMU and a value less than 1 shows an inefficient DMU.

In order to fulfil the basic concepts of DEA, some tests are conducted to the input and output variables used. The tests are exclusivity, homogenity, degree of freedom, numerical, and positivity. According to Budi cit. Wahyudi (2014), those tests are required in order to generate reliability and no bias value of efficiency.

Once the basic concepts are met, DEA is done by constant returns to scale (CRS) and variable returns to scale (VRS) assumptions. According to Favero and Papi cit. Marwa and Aziakpono (2016), basically DEA derives the data envelopment surface by joining those points in the input-output space such that it is no longer possible to produce more output with the same input or the same output with less input. In case of CRS, the frontier will be linear, and for VRS the frontier will be convex hull.

In this study, the scope of efficiency is limited to technical efficiency only. TE is estimated by measuring the ratio of the distance between reference point's distance to constant returns to scale frontier and inefficient firm's distance from the same frontier (Marwa and Aziakpono, 2016). As Huang et al. (2013) argues, TE can be measured from either an 
Table 1. Number of KUD in Yogyakarta Special Region and Number of DMU

\begin{tabular}{lccc}
\hline Regency/Municipality & Number of KUD & Number of DMU & $\begin{array}{c}\text { Ratio between Number } \\
\text { of KUD and Number of } \\
\text { DMU (\%) }\end{array}$ \\
\hline Bantul & 17 & 7 & 41.17 \\
Sleman & 17 & 8 & 47.05 \\
Gunungkidul & 16 & 7 & 43.75 \\
Kulon Progo & 12 & 10 & 83.33 \\
Yogyakarta & 1 & 0 & 0.00 \\
Yogyakarta Special & 63 & 32 & s50.79 \\
Region & & & \\
\hline
\end{tabular}

Table 2. The Result of Exclusivity Test of Input and Output Variable(s)

\begin{tabular}{|c|c|c|c|c|c|c|c|c|c|}
\hline $\begin{array}{l}\text { Input and Output } \\
\text { variable(s) }\end{array}$ & NM & NDS & NMA & $\mathrm{E}$ & $\mathrm{EC}$ & MAE & DSH & DP & BV \\
\hline $\mathrm{NM}$ & 1.00 & -0.06 & 0.68 & 0.05 & 0.04 & 0.20 & 0.29 & -0.10 & 0.36 \\
\hline NDS & -0.06 & 1.00 & 0.09 & 0.18 & -0.01 & 0.06 & 0.10 & 0.02 & -0.03 \\
\hline NMA & 0.68 & 0.09 & 1.00 & 0.41 & -0.05 & 0.27 & 0.59 & 0.24 & 0.37 \\
\hline $\mathrm{E}$ & 0.05 & 0.18 & 0.41 & 1.00 & -0.26 & 0.28 & 0.59 & 0.08 & 0.09 \\
\hline $\mathrm{EC}$ & 0.04 & -0.01 & -0.05 & -0.26 & 1.00 & 0.32 & -0.13 & -0.04 & 0.32 \\
\hline MAE & 0.20 & 0.06 & 0.27 & 0.28 & 0.32 & 1.00 & 0.54 & 0.41 & 0.45 \\
\hline DSH & 0.29 & 0.10 & 0.59 & 0.59 & -0.13 & 0.54 & 1.00 & 0.39 & 0.26 \\
\hline DP & -0.10 & 0.02 & 0.24 & 0.08 & -0.04 & 0.41 & 0.39 & 1.00 & 0.10 \\
\hline BV & 0.36 & -0.03 & 0.37 & 0.09 & 0.32 & 0.45 & 0.26 & 0.10 & 1.00 \\
\hline
\end{tabular}

input-oriented perspective or an output-oriented perspective. TE measured from an output-oriented perspective means the ratio of the actual outputs to the outputs on the production frontier given the level of inputs, whereas TE measured from an input oriented perspective refers to the ratio of the input on the production frontier to the actual inputs given the level of output.

TE is decomposed into pure technical efficiency and scale efficiency. Pure technical efficiency is measured as the ratio of the distance between inefficient points to variable return to scale efficient frontier. Scale efficiency measures the ratio of the production frontier under CRS to the production frontier under VRS (Huang et al., 2013).

In this study, number of member, number of director and supervisor, number of manager and administrator, equity, external capital, managers and administrator earnings, as well as directors and supervisors honorary, employed as input variables. Meanwhile, the outputs are dividend profit and business volume.

When the efficiency level is known, the next step is todetermine the factors affecting efficiency level. The score that resulted from DEA used as dependent variable, while explanatory variables are age $\left(\mathrm{X}_{1}\right)$, incentive $\left(\mathrm{X}_{2}\right)$, donation $\left(\mathrm{X}_{3}\right)$, accounts receivable $\left(\mathrm{X}_{4}\right)$, total assets $\left(\mathrm{X}_{5}\right)$, and dummy variables (savings and loans $\left(D_{1}\right)$, agriculture inputs $\left(D_{2}\right)$, rice milling $\left(D_{3}\right)$, electricity services $\left(D_{4}\right)$, grocery $\left(D_{5}\right)$, internet services $\left(D_{6}\right)$, and hand tractor $\left(D_{7}\right)$. Mathematically, the relationship between the dependent variable and the independent variable is shown in equation (1).

\section{RESULT AND DISCUSSION}

\section{Number of DMU}

In 2016, Yogyakarta Special Region has 63 KUD that spread over its regency and municipality. In order to determine the level of efficiency, this study employed DEA. Before using the DEA, there are several basic concepts that must be fulfilled in terms of generate reliability and no bias value of efficiency. Two of which are numerical and positivity. Numerical and positivity mean that the data used both input and input variables must be numeric and has positive value $(>0)$. It is found that out of $63 \mathrm{KUD}$, only 32 
Table 3. Technical and Scale Efficiency Scores of KUD in Yogyakarta Special Region, 2011-2012

\begin{tabular}{|c|c|c|c|c|c|c|c|c|c|c|c|c|}
\hline \multirow{3}{*}{$\begin{array}{c}\text { Efficiency range } \\
<0.10\end{array}$} & \multicolumn{4}{|c|}{ TE } & \multicolumn{4}{|c|}{ PTE } & \multicolumn{4}{|c|}{$\mathrm{SE}$} \\
\hline & \multicolumn{2}{|c|}{2011} & \multicolumn{2}{|c|}{2012} & \multicolumn{2}{|c|}{2011} & \multicolumn{2}{|c|}{2012} & \multicolumn{2}{|c|}{2011} & \multicolumn{2}{|c|}{2012} \\
\hline & 0 & $0 \%$ & 2 & $6 \%$ & 0 & $0 \%$ & 0 & $0 \%$ & 0 & $0 \%$ & 2 & $6 \%$ \\
\hline $0.11-0.20$ & 1 & $3 \%$ & 2 & $6 \%$ & 0 & $0 \%$ & 0 & $0 \%$ & 1 & $3 \%$ & 0 & $0 \%$ \\
\hline $0.21-0.30$ & 6 & $19 \%$ & 5 & $16 \%$ & 0 & $0 \%$ & 0 & $0 \%$ & 3 & $9 \%$ & 4 & $13 \%$ \\
\hline $0.31-0.40$ & 5 & $16 \%$ & 6 & $19 \%$ & 0 & $0 \%$ & 0 & $0 \%$ & 5 & $16 \%$ & 8 & $25 \%$ \\
\hline $0.41-0.50$ & 3 & $9 \%$ & 2 & $6 \%$ & 0 & $0 \%$ & 0 & $0 \%$ & 3 & $9 \%$ & 1 & $3 \%$ \\
\hline $0.51-0.60$ & 1 & $3 \%$ & 1 & $3 \%$ & 1 & $3 \%$ & 1 & $3 \%$ & 3 & $9 \%$ & 1 & $3 \%$ \\
\hline $0.61-0.70$ & 1 & $3 \%$ & 2 & $6 \%$ & 2 & $6 \%$ & 1 & $3 \%$ & 1 & $3 \%$ & 4 & $13 \%$ \\
\hline $0.71-0.80$ & 0 & $0 \%$ & 1 & $3 \%$ & 3 & $9 \%$ & 3 & $9 \%$ & 0 & $0 \%$ & 0 & $0 \%$ \\
\hline $0.81-0.90$ & 1 & $3 \%$ & 1 & $3 \%$ & 4 & $13 \%$ & 1 & $3 \%$ & 1 & $3 \%$ & 2 & $6 \%$ \\
\hline $0.91-0.99$ & 2 & $6 \%$ & 0 & $0 \%$ & 1 & $3 \%$ & 6 & $19 \%$ & 3 & $9 \%$ & 0 & $0 \%$ \\
\hline 1 & 12 & $38 \%$ & 10 & $31 \%$ & 21 & $66 \%$ & 20 & $63 \%$ & 12 & $38 \%$ & 10 & $31 \%$ \\
\hline Total & 32 & $100 \%$ & 32 & $100 \%$ & 32 & $100 \%$ & 32 & $100 \%$ & 32 & $100 \%$ & 32 & $100 \%$ \\
\hline Mean & 0.64 & & 0.57 & & 0.92 & & 0.94 & & 0.68 & & 0.60 & \\
\hline
\end{tabular}

KUD can be used as DMU and next to be measured with DEA (Tabel 1).

When numerical and positivity tests are done, the next basic concepts that must be done are exclusivity, homogenity, and degree of freedom. Budi cit. Wahyudi (2014) explained that the exclusivity test ensured a variable is not a part of another variable used in DEA. Correlation test is used to measure the association among variables used. A variable is considered strongly correlated with other variables if the correlation score is $\geq 0.8$. Referring to Table 2 , it is known that the scores of correlation test for each variable is below 0.8 .

Meanwhile, through the test of homogenity, it is concluded that the input and output variables are the same type and identic. The difference is only lies on the intensity and magnitude of the number/size. The last basic concept is degree of freedom. It passed the test because the DMU (32 DMU) used for this study more than three times of the sum of input and output variables

Technical and scale efficiency scores of KUD in Yogyakarta Special Region showed on Table 3. Table 3 indicates that the mean values of overall technical (TE), pure technical (PTE), and scale efficiency (SE) in 2011 are $0.64,0.92$, and 0.68 , respectively. In the next period, the scores of TE and SE decline to 0.57 and 0.60 , respectively. However, PTE score in 2012 is 0.02 higher than the previous year.

Empirical results on Table 3 suggest that there are significant possibilities to increase TE level, one of which is to reduce the inefficiency. Othman et al. (2014) explained that reducing the inefficiency means reducing the consumption of all inputs used. For instance, the mean score of TE in 2011 is 0.64 and 0.57 in 2012. These scores imply that the KUD on the whole should reduce their consumption of all inputs by $36 \%$ in 2011 and $43 \%$ in 2012. As for VRS (mean scores 0.92 in 2011 and 0.94 in 2012), the KUD's consumption of all inputs should be reduced to $8 \%$ and $6 \%$, to become efficient. Moreover, Krasachat and Chimku (2009) mentioned that adopting the best practices of efficient co-operatives can be one of the ways to eliminating the inefficiency.

Referring to Table 3, based on CRS in 2011, only $38 \%$ of the KUD are efficient, while VRS $66 \%$ are efficient. In 2012, CRS are $31 \%$ and VRS 63\%. The gap between the percentages of efficient groups between CRS and VRS is quite large. Ramanathan (2003) cit. Othman et al. (2014) said that the difference between those two models is caused by the assumption of CRS is relaxed as VRS variables are assumed.

Individually, in 2011, the results showed that among $32 \mathrm{KUD}$, there are $12 \mathrm{KUD}$ that have efficiency scores 1 or $100 \%$ based on the assumption of constant returns to scale, while $21 \mathrm{KUD}$ achieve efficient when applying the variable returns to scale assumptions. Another point showed in Table 3 is that under VRS assumption, it is found higher efficiency scores for all KUD and more efficient KUD. The reason is because KUD operating efficiently under CRS accompanied by new efficient KUD that might be operated under either increasing returns to scale or 
Table 4. Returns to Scale of KUD in Yogyakarta Special Region, 2011 - 2012

\begin{tabular}{ccccc}
\hline \multirow{2}{*}{ Returns to Scale } & \multicolumn{2}{c}{2011} & \multicolumn{3}{c}{2012} \\
\cline { 2 - 5 } & Number of DMUs & $\%$ & Number of DMUs & $\%$ \\
\hline Decreasing Returns to Scale & 0 & 0.00 & 0 & 0.00 \\
Increasing Returns to Scale & 20 & 62.50 & 22 & 68.75 \\
Constant Returns to Scale & 12 & 37.50 & 10 & 31.25 \\
\hline Total & 32 & 100.00 & 32 & 100.00 \\
\hline
\end{tabular}

Table 5. Determinants Factors of KUD Efficiency Level

\begin{tabular}{|c|c|c|c|c|c|c|}
\hline \multirow{2}{*}{ Variable } & \multicolumn{2}{|c|}{ TE } & \multicolumn{2}{|c|}{ PTE } & \multicolumn{2}{|c|}{$\mathrm{SE}$} \\
\hline & Coefficient & Prob. & Coefficient & Prob. & Coefficient & Prob. \\
\hline Constant & 0.50 & 0.45 & 1.24 & 0.00 & 0.37 & 0.56 \\
\hline Age & 0.02 & 0.41 & 0.00 & 0.92 & 0.02 & 0.35 \\
\hline Donation & 0.00 & 0.86 & 0.00 & 0.76 & 0.00 & 0.89 \\
\hline Incentive & $0.00 *$ & 0.06 & 0.00 & 0.32 & $0.00 *$ & 0.07 \\
\hline Accounts receivable & 0.00 & 0.63 & $0.00 * * *$ & 0.00 & 0.00 & 0.89 \\
\hline Total assets & 0.00 & 0.71 & 0.00 & 0.32 & 0.00 & 0.89 \\
\hline Savings and loan & 0.08 & 0.80 & -0.05 & 0.68 & 0.11 & 0.72 \\
\hline Agriculture inputs & $0.54 * * *$ & 0.00 & $0.09 *$ & 0.05 & $0.52 * * *$ & 0.00 \\
\hline Electricity & $-1.08 * *$ & 0.01 & -0.22 & 0.15 & $-1.01 * *$ & 0.01 \\
\hline Rice Milling & $-0.27 * *$ & 0.02 & $-0.09 * *$ & 0.03 & $-0.21 * *$ & 0.04 \\
\hline Grocery & 0.12 & 0.21 & -0.01 & 0.74 & 0.13 & 0.14 \\
\hline Internet services & 0.14 & 0.17 & -0.01 & 0.72 & 0.15 & 0.12 \\
\hline Hand Tractor & $0.45^{*}$ & 0.05 & 0.05 & 0.57 & $0.41 *$ & 0.06 \\
\hline R-squared & \multicolumn{2}{|c|}{0.44} & \multicolumn{2}{|c|}{0.41} & \multicolumn{2}{|c|}{0.44} \\
\hline Adjusted R-squared & \multicolumn{2}{|c|}{0.30} & \multicolumn{2}{|c|}{0.27} & \multicolumn{2}{|c|}{0.31} \\
\hline F-statistic & \multicolumn{2}{|c|}{3.29} & \multicolumn{2}{|c|}{2.97} & \multicolumn{2}{|c|}{3.32} \\
\hline Prob(F-statistic) & \multicolumn{2}{|c|}{0.00} & \multicolumn{2}{|c|}{0.00} & \multicolumn{2}{|c|}{0.00} \\
\hline
\end{tabular}

decreasing returns to scale (Segun and Anjugam, 2013). The KUD that remain technically efficient under both CRS and VRS assumption are Tani Makmur, Bhina Rejeki, Margomulyo, Mekar, Subur, Sumber Mulyo, Widodo, Sarimulyo, Girikencono, Seyegan, Godean, and Ngemplak.

Abidin and Endri (2009) explained that a KUD can achieve the highest level of efficiency, scored 1 or $100 \%$, if it had been able to make efficiencies in the use of inputs nor have been able to take advantage of all its potential ability to produce outputs. Instead, a KUD that has efficiency score below $100 \%$ should use inputs efficiently or maximize all of its potential ability to produce output.

In 2012, under CRS assumption, the number of KUD that have efficiency score 1 decreased by 2 KUD, namely: Girikencono and Ngemplak. In addition, there are also KUD where in 2011 inefficient and in 2012 become more inefficient, those are: Hemat (-3.17\%), Pleret (-32.39\%), Surti (-58.63\%), Tani Binangun (-39.35\%), Tani Rejo (-26.34\%), Sumber Raharjo (-35.77\%), Makmur (-19.12\%), Sido Subur (-32.19\%), Sidoluhur (-12.16\%), Rejeki Mulyo (-29.90\%),
Sidotentrem (-18.12\%), Girikencono (-17.98\%), Sedyo Rahayu (-29.29\%), Tani Manunggal (-1.86\%), Moyudan (-8.67\%), Prambanan (-34.1\%), Barata (-31.15\%), Gamping (-25.24\%), and Ngemplak (-21.95\%). On the other hand, even though it has not been able to achieve efficient, there are 2 KUD that experienced increasing of efficiency score from 2011 to 2012, namely: Tani Harjo (12.01\%) and Bangun (38.24\%).

When VRS assumption is taken, it is found that there is one KUD that achieve maximum efficiency in 2011, but in 2012 they experienced decreasing of the efficiency score, that is Ngemplak. Nevertheless, there are several KUD that experienced increasing of the efficiency score from 2011 to 2012, which are Pleret, Makmur, Gangsar, Sidotentrem, Sedyo Rahayu, Tani Manunggal, Prambanan, and Gamping.

The increasing scores are $3.68 \%, 5.29 \%, 13.34 \%$, $18.64 \%, 0.35 \%, 4.39 \%, 15.36 \%$, and $32.74 \%$, respectively. On the other side, 4 KUD become more inefficient from 2011 to 2012, namely: Tani Binangun (-0.02\%), Sido Subur (-0.67\%), Moyudan (-0.10\%), and Barata $(-9.76 \%)$.

SE came from dividing the score of TE and PTE. 
Referring Table 3, the average scores of SE in 2011 and in 2012 are 0.68 and 0.60 . When SE score is below 1, it indicated that the majority of KUD are operating below the optimal scale. Another finding that can be explained from Table 3 is that PTE dominates the scale efficiency of KUD. When SE is dominated by PTE, it suggests that KUD are managerially efficient even though they are not operating at the optimal scale of efficiency.

Examining the returns to scale, it is found that in 2011 and 2012, $62.50 \%$ and $68.75 \%$ of KUD experience increasing returns to scale, respectively (See Table 4). Segun and Anjugam (2013) argued that when KUD experience economies of scale, it indicates that management of KUD still have to utilize the inputs efficiently to increase their technical efficiency in terms of generating dividend profit and business volume.

Table 5 reports the results of determinant factors of KUD efficiency level. As shown on Table 5, independent variables are age, donation, incentive, accounts receivable, total assets, and dummy variables (savings and loan, agriculture inputs, electricity services, rice milling, grocery, internet services, hand tractor). Dummy variable indicating whether KUD has each of those business unit or not.

As can be seen, the estimated coefficient of variable incentive is positive and statistically significant, meaning that incentive did have positive impact on $\mathrm{TE}$ and SE. It is clearly evident from the fact that KUD which are providing incentive to its director, supervisor, manager, and administrator increase their efficiency. Accounts receivable is found to be significant at 1 percent level and has positive only on the technical efficiency of KUD.

The dummy variable indicating KUD has agriculture inputs business unit is found to be significant at 1 percent and 10 percent for TE, SE, and PTE, respectively. Dummy agriculture inputs have positive coefficient, which means the existence of agriculture inputs business unit did have positive impact on TE, SE, and PTE. In other words, KUD that has agriculture inputs business unit would has higher technical efficiency than KUD that does not have. The existence of electricity services within KUD has negative influence on TE and SE scores. If a KUD has electricity services business unit, it would has less efficient level than KUD that does not have. KUD faces competition with the other business entities in terms of providing electricity services to the members nor non-members. While the revenue decreasing caused by losing consumer, the cost is still the same.

Next, the other dummy variables that statistically significant to technical efficiency are rice milling and hand tractor. Rice milling consistenly shows negative sign across various measures of efficiency, which mean the existence of rice milling business unit causes a decline in efficiency performance. The variable is found to be highly significant at $5 \%$ level for all types of efficiency (TE, PTE, and SE). This finding implies that KUD rice milling has resulted in lower efficiency performance of KUD. One of the reasons is KUD could not compete with slepan (a modified vehicle to mill the rice). Slepan has higher mobility, could access people even in the remote area, while KUD's rice milling is stay still at the same place, either wait for consumer to come or the management give an offer to the consumer to mill their rice at KUD.

Hand tractor has a positive relationship with KUD efficiency (TE and SE). The variable is found to be statistically significant in all types of efficiency except for pure technical efficiency case. The finding suggests that KUD that owns hand tractor business unit would has higher efficiency performance than KUD that does not own one. The main reason why KUD that has hand tractor became more efficient is because they do not need to maintain the hand tractor. The majority of KUD rent the hand tractor to members nor non-members for specified period. KUD receive the fee, while the maintenance cost is issued by consumer.

\section{CONCLUSION}

This study has analysed the efficiency level of KUD in Yogyakarta Special Region during 2011 and 2012 by utilizing data envelopment analysis and multiple regression analysis to determine the factors that affecting the efficiency level. The results find out that average scores are $64 \%, 92 \%$, and $68 \%$ for overall technical, pure technical and scale efficiency respectively in 2011, while in 2012 the average scores are $57 \%, 94 \%$, and $60 \%$ for overall technical, pure technical and scale efficiency respectively. Factors having significantly positive impact on several measures of efficiency are incentive and dummy variable (agriculture inputs and hand tractor). Accounts receivable only has positive relationship to pure technical efficiency. On the other hand, rice milling unit and electricity services have negative impact with several measures of efficiency. 


\section{REFERENCES}

Abidin, $\mathrm{Z}$ and Endri. 2009. Kinerja Efisiensi Teknis Bank Pembangunan Daerah: Pendekatan Data Envelopment Analysis (DEA). ABFI Institute Perbanas. Jurnal Akuntansi dan Keuangan, 11(Mei), pp.21-29.

Altman, M. 2015. Cooperative Organizations as An Engine of Equitable Rural Economic Development. Journal of Co-operative Organization and Management, 3(1) Jun., pp.14-23.

Ariyaratne, C. B., M.F. Allen; R.L. Michael and G.B. David. 2000. Measuring X-efficiency and Scale Efficiency for a Sample of Agricultural Cooperatives. Agricultural and Resource Economics Review, 29/2 Oct., pp.198-207.

Davis, Peter. 2010. Mengembangkan Keunggulan Koperasi. Malang: LSP2I. pp.158.

Djohan, D. 1997. Setengah Abad: Pasang Surut Gerakan Koperasi Indonesia 12 Juli 1947 12 Juli 1997. Jakarta: Dewan Koperasi Indonesia.

Liliana, D. and C. Duguleana. 2015. Data Envelopment Analysis for the Efficiency of Academic Departments. Bulletin of the Transilvania University of Braşov Series V: Economic Sciences, 8:57(2).

Ganesan N. 2009. Data Envelopment Analysis of State and District Cooperative Banks in India: Exploratory Results. The IUP Journal of Bank Management, 8(3\&4).

Hadisapoetro, S. 1975. Kelengkapan Wilayah Unit Desa Masalah dan Prospeknya. Yogyakarta: Fakultas Pertanian Universitas Gadjah Mada.

Huang, Z.; Y. Fu, Q. Liang; Y. Song, X. Xu. 2013. The Efficiency of Agricultural Marketing Cooperatives in China's Zhejiang Province: Efficiency of Agricultural Marketing Cooperatives in China. Manag. Decis. Econ., 34, pp.272-282.
Jamhari, L.R. Waluyanti, P.S. Abi and N.D. Chandarisma. 2015. Strategi Pengembangan KUD di DIY (Studi Kasus: KUD Barata di Kabupaten Sleman). Yogyakarta: Fakultas Pertanian Universitas Gadjah Mada.

Krasachat, W. and K. Chimkul. 2009. Performance Measurement of Agricultural Coopertives in Thailand: An Accounting-Based Data Envelopment Analysis. In Productivity, Efficiency, and Economic Growth in the Asia-Pacific Region. Berlin: Springer.

Nyankomo, M. and M. Aziakpono. 2016. Technical and Scale Efficiency of Tanzanian Saving and Credit Cooperatives. The Journal of Developing Area, 50(1).

Othman, A., N. Mansor, F. Kari. 2014. Assessing the Performance of Co-operatives in Malaysia: An Analysis of Co-operative Groups Using A Data Envelopment Analysis Approach. Asia Pac. Bus. Rev., 20, pp.484-505.

Rossazana, A.R., N.G. Md-Nor, S. Ramlee and N.Z. Ubaidillah. 2012. Determinants of Cost Efficiency in Malaysian Banking. International Journal of Business and Society, 13(3), pp. 355-374.

Segun, K. R. S. and M. Anjugam. 2013. Measuring the Efficiency of Sub-Saharan Africa's Microfinance Institutions and Its Drivers. Annal of Public and Cooperative Economics, 84(4), pp.399-422.

Wahyudi. 2014. Efisiensi Pelayanan Kesehatan Dasar di Kabupaten Pemalang Menggunakan Data Envelopment Analysis. Theses. Yogyakarta: Universitas Gadjah Mada. 